\title{
Specifics of managerial decisions made by the heat-supplying organizations management during the selection of the partner organizations
}

\author{
Natalia $G$ Verstina, and Natalia $M$ Fomenko* \\ Moscow State University of Civil Engineering, Yaroslavskoe shosse, 26, Moscow, 129337, Russia
}

\begin{abstract}
The issue of the selection of business partners in the conditions of the uniform heat-supplying organizations functioning is considered in the article. The need of quality and timely evaluation of the potential partners for the purpose of the increase in the level of quality of generation, transportation and distribution of heat energy is proved. The author's approach of holding the procedure of selection of the most reliable partner was used with the help of the method of the hierarchical analysis. The method of pair comparisons was also applied within the research, the blocks and indicators of the assessment were defined. The model of additive convolution was chosen as the method of the aggregated criterion creation.
\end{abstract}

\section{Introduction}

In modern market conditions special attention is paid to the issues of forming of new communications and interactions among the partner organizations when forming of value creation chain. Business partnership is the form of such cooperation. Business partnership allows to increase the efficiency of activity of each participant by the means of association of resources, including innovations, technologies, capital and labour as well as the means of risk mitigation.

The choice of a partner for the organization is one of the main matters in any organization management. In the modern market there are many firms providing similar goods (services), which reliability and business reputation is determined only by financial performance. Great quantity of potential partners and their variety increases the relevance of the matter of the choice of those which would provide the maximum effect and reliability of implementation of the processes of value creation chain. The process of the partners selection was investigated in the works by Berkovich V. [1], Bukhonov S. [2] Suloyev S. [3], Yashin A. [4], etc. Most of scientists are unanimous in the opinion that the solution of this task is the multistage process and consists of several stages which are in continuous communication with each other: search of the potential partners, their analysis and evaluation of cooperation.

This subject is especially important in the heat supply industry where the main role of coordination and regulation of process of heat supply within certain territory, belongs to the uniform heat-supplying organizations (HSO). It is obvious that HSO interacts with great quantity of partners within its activity. Therefore, when determining the circle of partners of HSO the authors group them according to the sign of participation in the main and auxiliary processes of the value creation chain.

The partners involved in the implementation of the main processes have rigid territorial binding, i.e. all the organizations which generate and deliver power, are deployed within the zone of functioning of HSO. Such organizations include the heat-supplying organizations having the large generating capacities with combined heat and power plants, similar organization with less powerful sources (boilers, heating systems specializing in transportation and distribution of heat energy through the high-level and distribution networks to consumers). Suppliers of fuel resources for generation of heat energy represent certain exception. That allows to increase the options of their choice $[5,6,7,8,9]$.

The lack of rigid binding to the territory of HSO. functioning is the feature of the choice of strategic partners who treat the auxiliary processes of value creation chain. It is possible to distinguish such partners as educational institutions, consulting organizations, suppliers of resources, organizations rendering rated and financial services, investors and others.

It should be noted that if the partner organizations having territorial binding are strictly limited in the performance of their functions by the one of HSO. functioning, then the availability of great quantity and variety of firms in the market, the potential business partners of HSO. located out of the territory of its functioning, providing similar goods and services offers great prospects of their choice $[9,10,11]$.

Nowadays scientists and practicians note, that the process of selection of partners within HSO. has no due justification and it is carried out on the basis of the accidental choice: personal preferences, experience of last transactions, analysis of the financial documents, put in the general access, tender procedures and so on. As a

Corresponding author: fnata77@mail.ru 


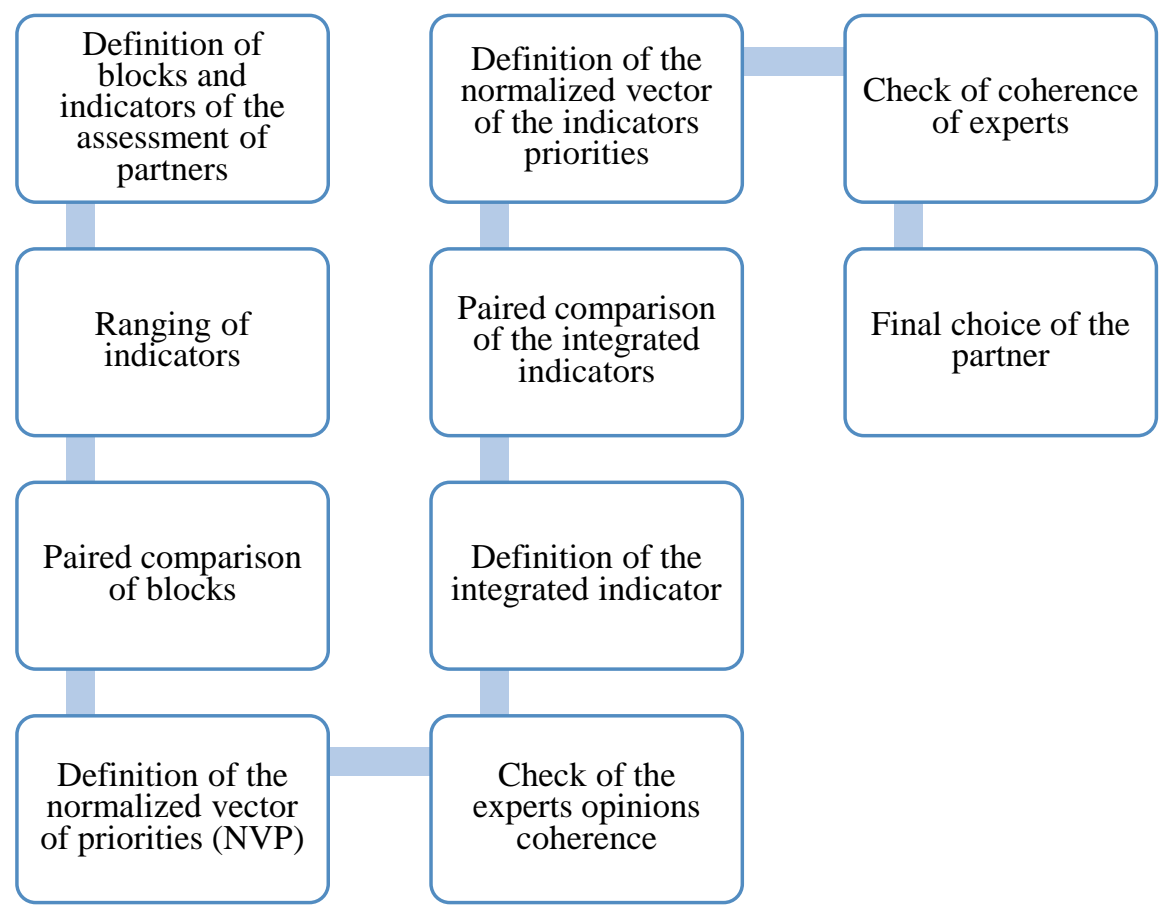

Fig. 1. Scheme of the solution of the problem of selection of business partners for HSO.

result of the accidental and unreasonable approach there are numerous risk situations of ensuring process of heat supply in terms of reliability and quality of implementation of contractual obligations, and high social responsibility of $\mathrm{HSO}$. as the guarantor of providing reliable and qualitative heat supply determines the need of development of the unified model of the choice of the partner during the implementation of process of generation, transportation and distribution of heat energy.

Unlike the works by other authors, the authors' approach to the justification of managerial decisions at HSO during the selection of the external partner organizations on the basis of the developed assessment.

\section{Materials and Methods}

According to the theory of managerial decisions, making the choice of the business partner of HSO. is one of the unstructured tasks. Their modeling at the quantitative level is difficult, as the majority of parameters of the assessment has qualitative character. In this case the application of expert estimates is appropriate. At the same time decision-making comes down to the choice of one of the alternatives. However, the feature of multicriteria tasks is that there is no alternative which would have the best values according to all the criteria. One of the tools of the solution of multicriteria tasks is the method of the analysis of hierarchies (MAH), developed by $\mathrm{T}$. Saati $[12,13]$. This method has special relevance for the practice-oriented tasks of the multicriteria optimization. The main advantages of this method include the possibility of accounting of many both quantitative and qualitative optimality criteria. $\mathrm{MAH}$ allows to evaluate the alternative options on the basis of calculation of priorities (relative importance) by the means of the procedure of pair comparisons. Considering the qualitative nature of information during the solution of the problem of the choice of partners, the application of nonmetric scaling is considered to be more reasonable. Ranging of the scale definition will be carried out by method of pair comparisons within this research.

The sequence of the solution of problem of selection of business partners of HSO. on the basis of their preliminary estimate for the purpose of the choice of the best option, is presented in Figure 1.

Within the conducted research authors distinguished five main blocks of the assessment of potential HSO. partners: "Technology potential", "Conscientiousness of cooperation", "Digital maturity", "Ability to innovations", "Territorial arrangement and infrastructure" (Table 1). When choosing the indicators included in the proper group, the authors was guided by the reference experience of estimation of the organizations used for the determination of potential of their development during the implementation of any projects including interaction of several partnering parties $[14,15,16,17,18,19,20,21]$.

Let us carry out the procedure of estimation of the priority criteria for the blocks of criteria for the example of the choice of suppliers of resources according to the offered scheme. Four suppliers whose main functional objective is the delivery of resources for operation of the heat supply system apply for the role of the business partner of HSO. The group of experts, representatives of the HSO make the decision.

The preliminary ranging of criteria in the decreasing order of importance is carried out for the definition of scales of indicators: 
Table 1. Indicators of the assessment of business partners.

\begin{tabular}{|c|c|c|c|}
\hline \#\# & $\begin{array}{l}\text { Blocks of criteria } \\
\text { (graphical symbol) }\end{array}$ & Criteria & Legend \\
\hline 1 & $\begin{array}{l}\text { "Technology potential" } \\
\text { (B1) }\end{array}$ & $\begin{array}{l}\text { Material and technical resources } \\
\text { Efficiency of the production processes } \\
\text { Level of the products (services) quality } \\
\text { Level of the infrastructure development } \\
\text { Level of mechanization and automation of production }\end{array}$ & $\begin{array}{l}\text { C1.1 } \\
\text { C1.2 } \\
\text { C1.3 } \\
\text { C1.4 } \\
\text { C1.5 }\end{array}$ \\
\hline 2 & $\begin{array}{l}\text { "Conscientiousness of } \\
\text { cooperation" (B2) }\end{array}$ & $\begin{array}{l}\text { Availability of long partner relationship with consumers and partners } \\
\text { Rapidity of the response to consumer requests change } \\
\text { Level of customer centricity ensuring } \\
\text { Possibility of resources sharing } \\
\text { Solvency level }\end{array}$ & $\begin{array}{l}\mathrm{C} 2.1 \\
\mathrm{C} 2.2 \\
\mathrm{C} 2.3 \\
\mathrm{C} 2.4 \\
\mathrm{C} 2.5\end{array}$ \\
\hline 3 & "Digital maturity" (B3) & $\begin{array}{l}\text { Digital transformation of operational processes } \\
\text { Intensity of the use of digital technologies } \\
\text { Level of digital maturity of management } \\
\text { Level of digital security } \\
\text { Intensity of the use of digital technologies }\end{array}$ & $\begin{array}{l}\text { C3.1 } \\
\text { C3.2 } \\
\text { C3.3 } \\
\text { C3.4 } \\
\text { C3.5 } \\
\end{array}$ \\
\hline 4 & $\begin{array}{l}\text { "Ability to innovations" } \\
\text { (B4) }\end{array}$ & $\begin{array}{l}\text { Ability to innovations implementation } \\
\text { Viability of innovations } \\
\text { Experience of the innovation projects implementation } \\
\text { Availability of the patents, useful models, developments, put on the company's balance } \\
\text { sheet and belonging to the enterprise } \\
\text { Provision with investment resources for financing of the innovation programmes and } \\
\text { projects }\end{array}$ & $\begin{array}{l}\text { C4.1 } \\
\text { C4.2 } \\
\text { C4.3 } \\
\text { C4. } \\
\text { C } 4\end{array}$ \\
\hline 5 & $\begin{array}{l}\text { "Territorial arrangement } \\
\text { and infrastructure" (B5) }\end{array}$ & $\begin{array}{l}\text { Structure of the industrial territory } \\
\text { Climatic, engineering-and-geological and topographical conditions of the area of the } \\
\text { partner location } \\
\text { Availability of the transport infrastructure } \\
\text { Level of the nfrastructure development } \\
\text { Engineering infrastructure }\end{array}$ & $\begin{array}{l}\text { C5.1 } \\
\text { C5.2 } \\
\text { C5.3 } \\
\text { C5.4 } \\
\text { C5.5 }\end{array}$ \\
\hline
\end{tabular}

$$
w\left(C_{1}\right)>w\left(C_{2}\right)>\ldots>w\left(C_{n}\right)
$$

Then it is necessary to carry out the paired comparison of blocks and indicators on their importance according to the nine-mark scale. The corresponding matrix of comparisons by dimension ( $n$ ) is formed for that purpose. Then the assessment of each of the chosen criteria according to certain scale, which priority estimates are: equal importance - 1; moderate superiority -3 ; significant superiority -5 ; strong superiority -7 ; very strong superiority -9 ; the use of even estimates is possible in intermediate cases: $2,4,6$, 8.

The results of pair comparisons of the importance for blocks are provided in Table 2.

Table 2. Matrix of estimates of the importance of blocks of the business partners assessment.

\begin{tabular}{|c|c|c|c|c|c|}
\hline Blocks & B1 & B2 & B3 & B4 & B5 \\
\hline B1 & 1 & 3 & 3 & 4 & 5 \\
\hline B2 & $1 / 3$ & 1 & 2 & 3 & 3 \\
\hline B3 & $1 / 3$ & $1 / 2$ & 1 & 3 & 2 \\
\hline B4 & $1 / 4$ & $1 / 3$ & $1 / 3$ & 1 & 4 \\
\hline B5 & $1 / 5$ & $1 / 3$ & $1 / 2$ & $1 / 4$ & 1 \\
\hline Total & 2.117 & 5.167 & 6.833 & 11.250 & 15.000 \\
\hline
\end{tabular}

The normalized vector of priorities (NVP) is estimated as follows:

a)the average geometrical in every line of matrix is calculated:

$$
\begin{aligned}
& a_{i}=\sqrt[n]{\prod_{j=1}^{n} a_{i j}}, \quad i=1,2, \ldots, n . \\
& a_{1}=\sqrt[5]{1 \cdot 3 \cdot 3 \cdot 4 \cdot 5}=2,82
\end{aligned}
$$

Then we found similarly: $\mathrm{a}_{2}=1.43 ; \mathrm{a}_{3}=1 ; \mathrm{a}_{4}=0.64$; $\mathrm{a}_{5}=0.38$.

b) the amount of average geometrical values is calculated:

$$
\begin{aligned}
& S=\sum_{i=1}^{n} a_{i} \\
& S=2.82+1.43+1+0.64+0.38=6.28
\end{aligned}
$$

c) components of NVP are calculated:

$$
\begin{aligned}
& N V P_{i}=\frac{a_{i}}{S}, \\
& l=1,2, \ldots n . \\
& N V P_{1}=\frac{2.82}{6.28}=0.44
\end{aligned}
$$

Similarly, we found: $\quad \mathrm{NVP}_{2}=0.22 ; \quad \mathrm{NVP}_{3}=0.16$; $\mathrm{NVP}_{4}=0.10 ; \mathrm{NVP}_{5}=0.06$

Coherence of estimates in the matrix is checked. Three characteristics are counted for this purpose:

a) own value of the matrix: 


$$
\begin{aligned}
& \lambda_{\max }=\sum_{i=1}^{n} N V P_{i} * \sum_{j=1}^{n} a_{i j} \\
& \lambda_{\max }=0.44 * 2.11+0.22 * 5.1+0.16 * 6.83+(5) \\
& +0.10 * 11.25+0.06 * 15=5.28
\end{aligned}
$$

b) approval index:

$$
\begin{aligned}
& A I=\frac{\lambda_{\text {max }}-n}{n-1} \\
& A I=\frac{5.28-5}{5-1}
\end{aligned}
$$

c) coharence relation:

$$
C R=\frac{A I}{I A C}
$$

where IAC is the indicator of accidental coherence, defined for the case when the estimates in the matrix are provided in a random way, and depending only on the size of the matrix (Table 3 ).
Table 4. IAC values.

\begin{tabular}{|c|c|c|c|c|c|c|c|c|c|c|}
\hline $\begin{array}{c}\text { Size of the } \\
\text { matrix }\end{array}$ & 1 & 2 & 3 & 4 & 5 & 6 & 7 & 8 & 9 & 10 \\
\hline IAC & 0 & 0 & 0.58 & 0.90 & 1.12 & 1.24 & 1.32 & 1.41 & 1.45 & 1.49 \\
\hline
\end{tabular}

According to Table 4, the indicator of accidental coherence for five criteria is 1.12 .

$$
A I=\frac{0.07}{1.12}=6.36
$$

The estimates in the matrix are considered to be coordinated if $\mathrm{CR}$ is $10 \ldots 15 \%$. If the value exceeds the threshold, it is necessary to carry out the assessment repeatedly. This indicator is $6.36 \%$ in our case, therefore the estimates of blocks in the matrix can be considered to be coordinated.

The similar procedure of comparison is carried out

\begin{tabular}{|c|c|c|c|c|c|c|c|c|c|c|}
\hline \multirow[b]{2}{*}{ Block } & \multirow[b]{2}{*}{ Criteria } & \multirow[b]{2}{*}{$\begin{array}{c}\text { Итоговые } \\
\text { вектора } \\
\text { приоритето } \\
\text { в критериев }\end{array}$} & \multicolumn{2}{|c|}{ Partner 1} & \multicolumn{2}{|c|}{ Partner 2} & \multicolumn{2}{|c|}{ Partner 3} & \multicolumn{2}{|c|}{ Partner 4} \\
\hline & & & 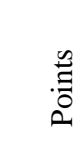 & 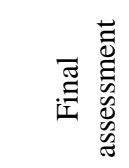 & 蒫 & 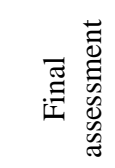 & 苛 & 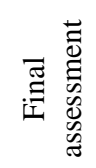 & 苂 & 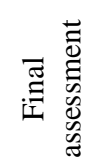 \\
\hline \multirow{5}{*}{ B1 } & C1.1 & 0.19 & 3 & 0.709 & 1 & 0.142 & 3 & 0.426 & 5 & 0.709 \\
\hline & C1.2 & 0.11 & 4 & 0.455 & 5 & 0.342 & 3 & 0.342 & 5 & 0.569 \\
\hline & C 1.3 & 0.09 & 3 & 0.272 & 2 & 0.109 & 3 & 0.163 & 5 & 0.272 \\
\hline & C1.4 & 0.04 & 3 & 0.118 & 5 & 0.197 & 2 & 0.079 & 5 & 0.197 \\
\hline & C1.5 & 0.02 & 2 & 0.055 & 3 & 0.082 & 5 & 0.138 & 4 & 0.11 \\
\hline \multirow{5}{*}{ B2 } & C2.1 & 0.10 & 3 & 0.546 & 5 & 0.437 & 5 & 0.546 & 2 & 0.218 \\
\hline & C2.2 & 0.06 & 4 & 0.19 & 5 & 0.239 & 4 & 0.191 & 3 & 0.143 \\
\hline & C2.3 & 0.04 & 3 & 0.094 & 4 & 0.075 & 4 & 0.075 & 5 & 0.094 \\
\hline & $\mathrm{C} 2.4$ & 0.02 & 2 & 0.032 & 3 & 0.048 & 4 & 0.064 & 5 & 0.065 \\
\hline & $\mathrm{C} 2.5$ & 0.01 & 4 & 0.041 & 5 & 0.031 & 4 & 0.042 & 3 & 0.031 \\
\hline \multirow{5}{*}{ B3 } & C3.1 & 0.05 & 2 & 0.168 & 4 & 0.337 & 4 & 0.337 & 4 & 0.337 \\
\hline & C3.2 & 0.03 & 2 & 0.065 & 5 & 0.164 & 3 & 0.098 & 5 & 0.164 \\
\hline & C3.3 & 0.02 & 2 & 0.051 & 5 & 0.129 & 2 & 0.051 & 4 & 0.103 \\
\hline & C3.4 & 0.02 & 3 & 0.062 & 2 & 0.041 & 2 & 0.041 & 4 & 0.083 \\
\hline & C3.5 & 0.03 & 4 & 0.051 & 3 & 0.038 & 5 & 0.064 & 3 & 0.039 \\
\hline \multirow{5}{*}{ B4 } & C4.1 & 0.04 & 2 & 0.144 & 4 & 0.289 & 4 & 0.289 & 4 & 0.289 \\
\hline & C4.2 & 0.03 & 3 & 0.171 & 1 & 0.057 & 5 & 0.286 & 3 & 0.171 \\
\hline & C4.3 & 0.02 & 4 & 0.073 & 2 & 0.037 & 3 & 0.056 & 3 & 0.055 \\
\hline & C4.4 & 0.01 & 5 & 0.073 & 3 & 0.044 & 3 & 0.044 & 5 & 0.074 \\
\hline & $\mathrm{C} 4.5$ & 0.01 & 5 & 0.036 & 4 & 0.029 & 2 & 0.014 & 3 & 0.022 \\
\hline \multirow{5}{*}{ B5 } & C5.1 & 0.02 & 5 & 0.138 & 5 & 0.138 & 3 & 0.083 & 3 & 0.083 \\
\hline & C5.2 & 0.01 & 3 & 0.039 & 5 & 0.065 & 4 & 0.052 & 1 & 0.013 \\
\hline & C5.3 & 0.01 & 4 & 0.072 & 4 & 0.072 & 5 & 0.09 & 5 & 0.09 \\
\hline & C5.4 & 0.01 & 2 & 0.012 & 5 & 0.031 & 6 & 0.037 & 3 & 0.019 \\
\hline & C5.5 & 0.01 & 3 & 0.028 & 5 & 0.047 & 6 & 0.057 & 1 & 0.009 \\
\hline \multicolumn{2}{|l|}{ TOTAL } & & 80 & 3.695 & 95 & 3.22 & 94 & 3.665 & 93 & 3.959 \\
\hline
\end{tabular}
for all the groups of indicators in each block. The final procedure of calculation of priorities of the indicators is carried out by multiplication of the priorities of each indicator by priorities of the corresponding blocks. Final vector of priorities of indicators within certain blocks for

Table 3. Final assessment of the potential partners. 
the choice of partners among suppliers of resources are provided in Table 4 .

\section{Results}

According to the expert estimates, points for all the listed criteria of each block are given to the participants with the help of the uniform scale. The final assessment of the participant is calculated with the use of additive convolution.

Additive convolution is the following:

$$
K(x)=\sum_{i=1}^{n} a_{i} K_{i}(x),
$$

where $\mathrm{K}(\mathrm{x})$ - is the general criterion for alternative $\mathrm{x}$, representing its suitability for the achievement of the goal; $\mathrm{x}$ - is the set of initial criteria; $\mathrm{n}$ - is the number of the initial criteria; $i$ - is the relative weight (importance) of a criterion. The normalization condition is necessary for the weights, so that the results received in different conditions were comparable.

The results are provided in Table 3. The higher the integrated assessment of the potential partner is, the more it meets the requirements of cooperation.

\section{Conclusion}

Thus, the most important criterion for the choice of partners among suppliers of resources are the criteria: material and technical resources, efficiency of production processes and availability of long partner relationship with consumers and partners as these organizations in the strategic partnership are responsible for timeliness and uninterrupted operation of the delivery of resources for operation of heating systems. According to the results of this example the Partner 4 is the best, as this partner has overall rating 3.959. At the same time it should be noted that according to final values of points (93 points) it concedes to the competitors: Partner 2 (95 points) and Partner 3 (94 points), but as the offered technique allows to consider the ratings of each estimated criterion in the general set during the decision making, the managerial decision on selection of strategic partners is made with great accuracy. The similar procedure should be carried out for all the potential partners of HSO. Getting the greatest positive points, the potential partner does not become the most attractive in comparison with the competitors, but exist as such a partner. At the same time the methodical provisions, offered for the evaluation of the potential partners in the conditions of their choice, can be applied both during the initial stage of the beginning of cooperation, and with the definite frequency (for example, annually) for the identification of dynamics of the partners development.

\section{References}

1. Berkovich V.M. Criteria for the evaluation of the potential partner on the compatibility in the conditions of modern logistics. INTEGRATED LOGISTICS. No. 6. pp. 23-24

2. Bukhonova S.M., Glagolev S.N., Karnaushenko O.A. Assessment and choice of the business partner. Himizdat. SPb. 2004. pp. 141

3. Suloyeva S.B., Nefedyev D.S. Model of the choice of priority business partners of an industrial enterprise. Scientific and technical sheets of SPBGPU. Economic sciences. No. 6-1(185). 2013. pp. 248-257

4. Yashin A. Choice of the business partner: without any right for mistake (Safety of business) .Economy and life. 1997. No. 34. pp. 30.

5. Federal law "About Heat Supply" of 27.07.2010 N 190-FZ. Access mode: http://www.consultant.ru/document/cons_doc_LAW _ 102975/ (Date of the address: 27.09.2020)

6. The standard of interaction of ETO with TSO. Access mode: https://www.tplusgroup.ru/fileadmin/user_upload/St andart_vzaimodeistvija_s_TSO.pdf (Date of the address: 25.09.2020);

7. Examination of industrial safety. Interaction of ETO. Access mode: https://tkexpert.ru/vocab/teplosnabzausaa-organizacia/ (Date of the address: 25.09.2020)

8. Uniform heatnetwork organization of St. Petersburg: advantages, perspectives, problems, current status. Access mode: https://gptek.spb.ru/press/ekspertnoemnenie/?ELEMENT_ID=134054 (Date of the address: 25.09.2020);

9. Timofeeva, A.A., Bulganina, S.V., Fomenko, N.M., Nekrasova, M.L., Zakharova, E.N. Features of the implementation of integrated marketing communications: Resistance to change / International Review of Management and Marketing, 2016, 6(1), pp. 27-32

10. Akhmetova I.G., Mukhametova L.R. Topical issues of increase in energy efficiency of the heatsupplying organizations//News of HIGHER EDUCATION INSTITUTIONS. Power problems. 2015. No. 11-12. URL: https://cyberleninka.ru/article/n/aktualnyevoprosy-povysheniya-energoeffektivnostiteplosnabzhayuschih-organizatsiy (date of the address: 25.09.2020).

11. Stennikov V. A., Penkovsky A. V., Postnikov I. V., Edeleva O.A., Mednikova E. E., Dobrovolskaya T. V., Sokolov P.A. Scientific and methodical ensuring optimum development of heat supply and its implementation in the territory of the Irkutsk region//the Messenger of IRGTU. 2019. No. 4 (147).

URL: https://cyberleninka.ru/article/n/nauchnometodicheskoe-obespechenie-optimalnogorazvitiya-teplosnabzheniya-i-ego-prakticheskaya- 
realizatsiya-na-territorii-irkutskoy (date of the address: 25.09.2020).

12. Ryabinkin V.N. Relationship of producers and consumers of heat energy. Practical grant Publishing house: Energoservice, 2006.

13. Saati T. L. Decision-making at dependences and feedback: Analytical networks. - M.: LKI publishing house, 2008. - 360 pages.

14. Saati T. L. Relative measurement and its generalization in decision-making. Why pair comparisons are key in mathematics for measurement of intangible factors//Cloud Of Science". 2016. T. 3. No. 2. C. 171-262 (https://cloudofscience.ru/sites/default/files/pdf/CoS _3_171.pdf)

15. Terebova Svetlana Viktorovna the Innovation capacity of the enterprise: structure and assessment//Scientific works: Institute of economic forecasting of RAS. 2017. No. 15. URL: https://cyberleninka.ru/article/n/innovatsionnyypotentsial-predpriyatiya-struktura-i-otsenka (date of the address: 27.09.2020).

16. Asaul, A. N. Productive and economic potential and business activity of subjects of business activity / A.N. Asaul, M.P. Voynarenko, S.Ya. Knyazev, T.G. Rzayeva; under the editorship of zasl. deit. sciences of the Russian Federation, Dr. ekon. sciences, prof. A.N. Asaul. - SPb.: ANO IPEV, 2011. - 312 pages.

17. Statistics of science and education. Release 1. Key indicators of development of the scientific organizations of the state academies of Sciences and Federal Agency for Scientific Organizations. Inf. to become. Mat. $-\mathrm{m}$ : to fgbn of scientific research institute rinktse, 2017. - 249 pages. Access mode: http://csrs.ru/archive/stat_2017_academy/academy_ 2017.pdf (date of the address: 27.09.2020).

18. Science indicators. Access mode: https://www.hse.ru/primarydata/in2019 (date of the address: 27.09.2020).

19. The ratings of the Expert RA agency on the organizations. Access mode: https://raexpert.ru/database/companies / (date of the address: 27.09.2020).

20. Ratings of the Fitch Ratings agency. Rating on the capacity of the Access Mode organizations: https://www.fitchratings.com/redirect/?q=/jsp/sector /Sector.faces/index.html (date of the address: 27.09.2020).

21. Verstina, N., Badalova, A., Evseev, E. Assurance of heating systems maintenance reliability through the creation of a risk management system of the heatsupplying organizations / E3S Web of Conferences, 2019. 